\title{
An Enzymatic Assay for Monitoring Serum, Cerebrospinal Fluid, and Urine Concentration of $\beta$-Lactam Antibiotics ${ }^{1}$ )
}

\author{
By W. Cullmann
}

Lehrstuhl für Med. Mikrobiologie und Immunologie der Ruhr-Universität Bochum

W. Dick

Zentrallabor des Lukaskrankenhauses Neuss and

\section{Edelmann}

Chirurgische Klinik des Knappschaftskrankenhauses Bochum-Langendreer-Universitätsklinik

(Received August 29/October 24, 1984)

Summary: August 29/October 24, 1984An enzymatic assay for the determination of the concentrations of various $\beta$-lactam antibiotics in serum, urine, and cerebrospinal fluid samples is described. Recently developed $\beta$-lactam derivatives are used as competitive inhibitors of the breakdown of the labile coloured $\beta$-lactam compound PADAC ${ }^{\oplus}$, which serves as the substrate for the various $\beta$-lactamases. Under the conditions of the assay, there is effectively no interference due to the matrix. Moreover, the assay is not influenced by other antibiotics such as aminoglycosides, macrolides, ansamycines, tetracyclines, fusidic acid or fosfomycin. The C.V.s for within-run precision ranged from $3.7 \%$ to $4.4 \%$, depending on the $\beta$-lactam derivative. The sensitivity of the assay is at least comparable with that of conventional procedures. Excellent correlations were observed between the enzymatic and the microbiological procedures; correlation coefficients: $r=0.988$ for 22 imipenem samples, $r=0.968$ for 16 cefotaxime samples, and $r=0.989$ for 16 piperacillin samples routinely sent to our laboratory.

\section{Enzymatische Bestimmung von B-Lactamantibiotika in Serum, Liquor und Urin}

Zusammenfassung: In der vorliegenden Arbeit wird ein enzymatisches Verfahren zur Bestimmung der Konzentration verschiedener $\beta$-Lactamantibiotika in Serum, Urin und Liquorproben beschrieben. Dieses Verfahren beruht auf der kömpetitiven Hemmung der Hydrolyse des chromogenen Cephalosporins PADAC ${ }^{\circledR}$, das als Substrat für die verschiedenen $\beta$-Làctamasen dient, durch die neueren $\beta$-Lactamderivate. Unter den vorgegebenen Bedingungen können Störungen. - bedingt durch die Matrix der Probe - weitestgehend ausgeschlossen werd̈en. Andere Antibiotika wie Aminoglykoside, Makrolide, Ansamycinderivate, Tetrazykline, Fusidinsäure und Fosfomycin stören die Bestimmung nicht. Die Präzision in der Serie schwankte in Abhängigkeit des $\beta$ Lactamderivates zwischen 3, $\overline{7}$ und 4,4\%. Die Empfindlichkeit des vorgeschlagenen enzymatischen Verfahrens ist durchaus mit derjenigen konventioneller Methoden vergleichbar. Der Vergleich des enzymatischen Verfahrens mit dem Bioassay (mikrobiologische Bestimmung) ergab eine ausgezeichnete Übereinstimmung: bei 22 Imipenem-Proben wurde ein Korrelationskoeffizient $r=0,988$, bei 16 Cefotaxim-Proben $r=0,968$ und bei 16 Piperacillin-Proben $\mathrm{r}=0,989$ erhalten.

1) Reported' in part at the "Biochemische Analytik '84" in Munich, April 1984 (1). 


\section{Introduction}

At present concentrations of $\beta$-lactam antibiotics are determined either by an agar diffusion test or by high performance liquid chromatography (2). As these methods are time-consuming and often require pretreatment of the samples, their routine use is restricted to experienced laboratories. The new methoxyiminocephalosporins are known to exhibit high affinity for the chromosomally mediated $\beta$ lactamase from Enterobacter cloacae and can be considered competitive inhibitors. This suggested the possible enzymatic determination of cefotaxime concentrations $(3,4)$ : hydrolysis of the labile coloured cephalosporin compound PADAC ${ }^{\circledR}$ was competitively inhibited by cefotaxime, and the inhibition of enzyme activity was related to the cefotaxime concentration (4). In a previous study it was demonstrated that most of the recently developed $\beta$-lactam compounds exhibit high affinity to $\beta$-lactamases and are fairly stable against breakdown by various enzymes. It seemed reasonable to explore the use of such an assay for the determination of a variety of therapeutically relevant compounds (5). The enzymatic assay can be scheduled as follows:

I. $\beta$-lactam compound $+\beta$-lactamase $\rightleftharpoons$ [inactive complex]

II. $\beta$-lactamase (remaining) $\rightleftharpoons$ hydrolysis of the substrate PADAC ${ }^{\circledR}$ (decrease in absorbance at $575 \mathrm{~nm}$ )

It had already been reported in the literature that PADAC ${ }^{\oplus}$ is well suited for this purpose, because there is no nonspecific cleavage of this compound by a biological matrix $(3,4)$. In the present work, such an enzymatic assay for various $\beta$-lactam compounds is described and compared with conventional procedures.

\section{Material and Methods}

Samples

All samples (serum, bile) investigated in this study were routinely sent to our laboratory and represented unselected clinical material. Bile samples ( $2 \mathrm{ml}$ aliquots) were collected in tubes containing $0.4 \mathrm{ml}$ morpholine propane sulphonate (MOPS) buffer $(0.1 \mathrm{~mol} / \mathrm{l})$ thus maintaining a final $\mathrm{pH}$ between 7.0 and 7.5 in the bile samples (6). A pool serum was obtained from 10 healthy donors. Cerebrospinal fluid was pooled from 20 samples sent to our laboratory which revealed no bacteria when cultured. Urine samples were obtained from healthy persons who had not received antibiotic treatment within the previous 4 weeks. All samples were analysed either at once or kept frozen for a maximum of 14 days at $-70^{\circ} \mathrm{C}$.

\section{Enzymes}

The TEM-1 enzyme (a broad-spectrum, plasmid-mediated $\beta$ lactamase) from $E$. coli $\mathrm{K} 12 \mathrm{R} 6 \mathrm{~K}$ was a commercially available preparation from Boehringer Mannheim (FRG). The Entero- bacter cloacae 2240 and the Citrobacter freundii 82 enzymes were prepared as described elsewhere without the second chromatographic step (7); the enzyme from Proteus vulgaris 4917 was prepared analogously.

\section{Equipment}

A Zeiss PM 7 (Carl Zeiss, Oberkochen) spectrophotometer with printer was used. A temperature of $25^{\circ} \mathrm{C}$ was maintained during all experiments. A triethanolamine buffer $(0.05 \mathrm{~mol} / \mathrm{l})$ adjusted to ph 7.5 was used throughout the experiments.

\section{Microbiological procedures}

For the microbiological determination of imipenem, cefotaxime, and piperacillin concentrations, the following strains were employed: Bacillus subtilis ATCC 6633 for imipenem (obtained from MSD Sharp \& Dohme, Munich), Escherichia coli $6311 / 65$ for cefotaxime (obtained from Hoechst A.G., Frankfurt), and Micrococcus luteus for piperacillin (obtained from Deutsche Sammlung für Mikroorganismen, strain no. 348, Göttingen). In each case, the assay was carried out according to the manufacturer's instructions.

\section{Reagents}

The antibiotics used in this study were obtained from the following sources:

ampicillin, cefuroxime, cefotaxime, HR $810, \mathrm{HR} 221$, and the quinolone compound ofloxacin from Hoechst A. G., Frankfurt (FRG);

oxacillin, mezlocillin, and azlocillin from Bayer Leverkusen (FRG);

piperacillin from Cyanamid Lederle, Wolfratshausen (FRG); ticarcillin, temocillin, and clavulanic acid from Beecham-Wülfing, Neuss (FRG);

ceftizoxime and fosfomycin from Boehringer Mannheim (FRG);

cefmenoxime and rifampicin (an ansamycine) from TakedaGrünenthal, Stolberg (FRG);

ceftriaxone from Hoffmann La Roche, Basel (Switzerland); ceftazidime from Cascan, Wiesbader (FRG);

cefoxitin, imipenem (synonym: $\mathrm{N}$-formimidoyl thienamycin), and cilastin from MSD Sharp \& Dohme, Munich (FRG);

lamoxactam from Eli Lilly, Gießen (FRG);

the monobactam aztreonam from Squibb-Heyden, Munich (FRG);

gentamicin from E. Merck Darmstadt (FRG);

fusidic acid, erythromycin, and tetracycline from Sigma Chem., Munich (FRG).

All other reagents of analytical grade were obtained from E. Merck, Darmstadt (FRG). The chromogenic cephalosporin compound 7-(thienyl-2-acetamido)-3-[2-(4-N,N-dimethylamino phenylazo)-pyridinium methyl]-3-cephem-4-carboxylic acid (PADÁC) was kindly supplied by Dr. $\dot{S} c h i n d l e r$, Hoechst A. G., Frankfurt (FRG); its molar absorption coefficient at $\lambda=575 \mathrm{~nm}$ was reported to be $40 \times 10^{3}\left(\mathrm{~m}^{2} / \mathrm{mol}\right)$ (4).

\section{Results}

\section{Methodological studies}

The $K_{\mathrm{m}}$-values for the enzymes employed and the chromogenic cephalosporin compound PADAC ${ }^{\circledR}$ are shown in table 1 . It is evident that the chromogenic 
Tab. 1. Properties of the $\beta$-lactamases used for enzymatic determination of $\beta$-lactam antibiotic concentrations.

\begin{tabular}{lll}
\hline Enzyme from & $K_{\mathrm{m}}$ & For determination of \\
\hline E. coli K 12 R6K: TEM-1 & $5.5 \times 10^{-5}$ & imipenems \\
Enterobacter cloacae 2240 & $1.2 \times 10^{-4}$ & penams (broad-spectrum penicillins) \\
Citrobacter freundii 82 & $1.7 \times 10^{-4}$ & $\begin{array}{l}\text { cephems (cephalosporins) } \\
\text { clavulanic acid; oxacillin in the presence of ampicillin or } \\
\text { Proteus vulgaris } 4917\end{array}$ \\
& $3.3 \times 10^{-5}$ & mezlocillin \\
\hline
\end{tabular}

compound exhibits only a moderate affinity for the enzymes. The substrate concentration should not exceed $5 \times 10^{-5} \mathrm{~mol} / 1$, which corresponds to an absorbance of 2.000 , e.i. substrate turnover should not exceed a fraction of 0.10 of the total substrate concentration, in order to maintain zero-order kinetics.

To rule out inferferences between the $\beta$-lactamase employed and the sample matrix we investigated whether the sample matrix influences enzyme activity. The activity of each enzyme decreased when the amount of serum (or bile) exceeded a volume fraction of 0.10 of the total assay volume (fig. 1). Similar findings were obtained for individual samples as well as for the pool serum. Urine and cerebrospinal fluid did not influence enzyme activity (data not shown). With due regard for these conditions, the assay can be scheduled as follows:

$0.40 \mathrm{ml} 0.05 \mathrm{~mol} / 1$ triethanolamine buffer containing the substrate PADAC ${ }^{\circledR}$ in a final concentration of $5 \times 10^{-5} \mathrm{~mol} / \mathrm{l}$,

$0.02 \mathrm{ml}$ sample and

$0.02 \mathrm{ml}$ enzyme solution;

measure decrease in absorbance during 1 or 2 minutes at $575 \mathrm{~nm}\left(25^{\circ} \mathrm{C}\right)$.

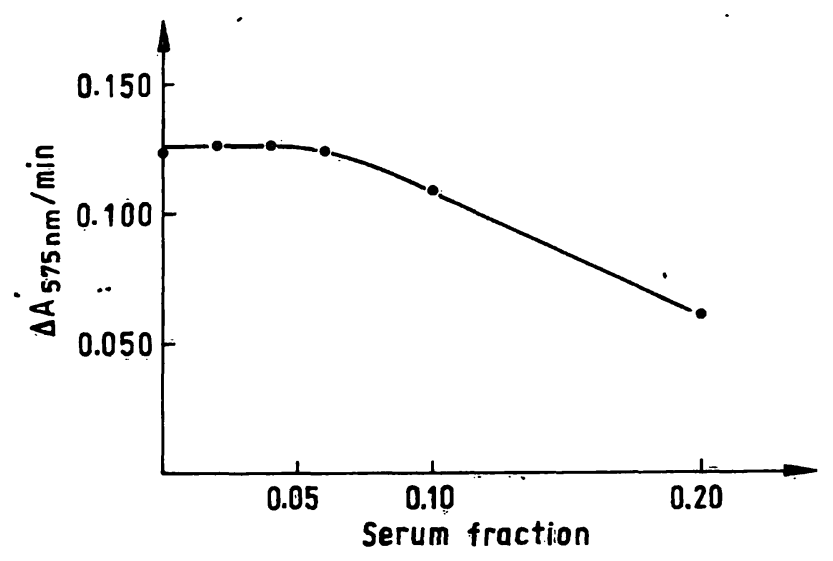

Fig. 1. Increasing amounts of serum in the reaction mixture cause a decrease of enzyme activity. Similar findings were made for all enzymes. No discrepancies existed between the pool serum and individual samples. Standard conditions; enzyme from Proteus vulgaris.
Enzyme catalytic concentration was adjusted to a decrease of absorbance of $\Delta A=0.100 / \mathrm{min}$. For the analysis of cerebrospinal fluid it may be useful to enhance the sensitivity of the assay; in these cases $0.05 \mathrm{ml}$ sample volume can be used. Both ticarcillin and ceftazidime are known to react slowly with the Enterobacter cloacae and the Citrobacter freundii enzyme, respectively. Therefore a preincubation period of at least 2 minutes was maintained before monitoring the decrease of absorbance.

With the above described conditions linear slope functions were obtained for all antibiotics listed in table 2; the data for imipenem are shown in figure 2. For therapeutic use imipenem is used in combination with cilastin - a dihydropeptidase inhibitor. Further experiments revealed that cilastin did not interfere with the enzymatic determination of imipenem. At present, concentrations of some new $\beta$-lactam compounds (temocillin, cefoperazone, cefsulodin, the compound HR 810, the oxacephem lamoxactam, and

Tab. 2. Sensitivity of the enzymatic assay for determination of $\boldsymbol{\beta}$-lactam antibiotic concentrations in biological fluids.

\begin{tabular}{llc}
\hline $\begin{array}{l}\beta \text {-Lactam } \\
\text { compound }\end{array}$ & Enzyme employed & $\begin{array}{l}\text { Sensitivity of } \\
\text { the assay } \\
\text { mg/l }\end{array}$ \\
\hline Imipenem & TEM-1 & $0.6-10$ \\
Cefuroxime & Citrobacter freundii & $0.04-0.9$ \\
Cefotaxime & Citrobacter freundii & $0.03-0.7$ \\
Cefmenoxime & Citrobacter freundii & $0.05-1.2$ \\
Ceftriaxone & Citrobacter freundii & $0.04-0.8$ \\
HR 221 & Citrobacter freundii & $0.3-7.5$ \\
Ceftizoxime & Citrobacter freundii & $1.5-40$ \\
Ceftazidime & Citrobacter freundii & $2.0-50$ \\
Cefoxitin & Citrobacter freundii & $1.5-40$ \\
Ampicillin & Enterobacter cloacae & $2.0-50$ \\
Mezlocillin & Enterobacter cloacae & $10-250$ \\
Azlocillin & Enterobacter cloacae & $4-90$ \\
Piperacillin & Enterobacter cloacae & $3-60$ \\
Ticarcillin & Enterobacter cloacae & $0.03-0.7$ \\
Oxacillin & Enterobacter cloacae & $0.01-0.3$ \\
Oxacillin & Proteus vulgaris & $2.0-50$ \\
Clavulanic acid & Proteus vulgaris & $0.5-10$ \\
\hline
\end{tabular}




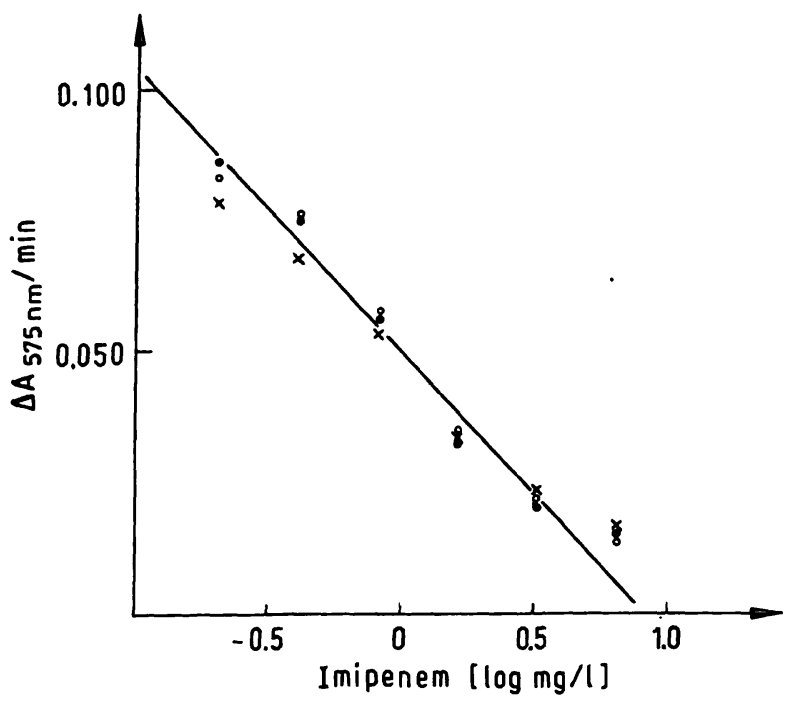

Fig. 2. Linearity of the enzymatic assay; analogous findings were obtained for all other compounds. $O$ pool serum, $x$ urine, and $\boldsymbol{O}$ buffer; standard conditions; enzyme from Enterobacter cloacae.

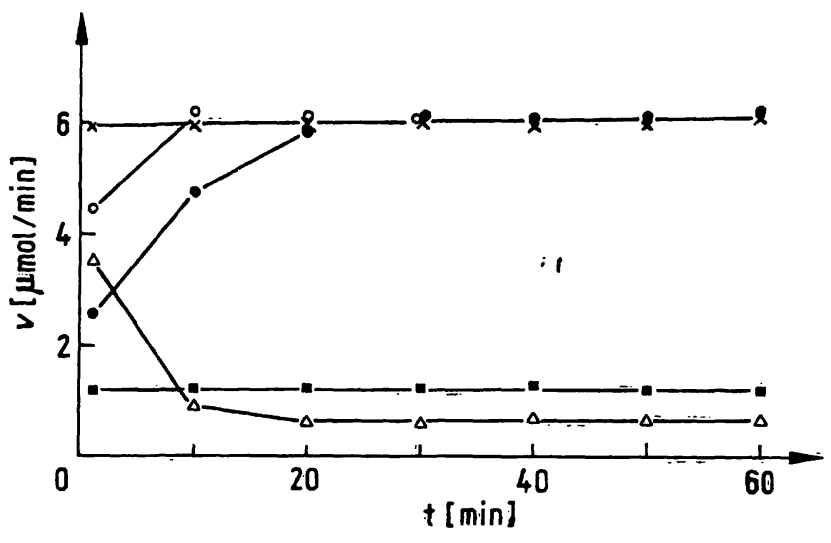

Fig. 3. Incubation of various $\beta$-lactam compounds with the enzyme from Proteus vulgaris. Aliquots were taken at various time intervals and the remaining enzyme activity was determined with the chromogenic compound PADAC

Ampicillin is rapidly broken down, whereas oxacillin is stable for 1 hour. Clavulanic acid inhibits the enzyme progressively.

O $10 \mathrm{mg} / \mathrm{l}$ ampicillin,

- $100 \mathrm{mg} / \mathrm{l}$ ampicillin,

ธ $10 \mathrm{mg} / \mathrm{l}$ oxacillin,

$\triangle 1 \mathrm{mg} / \mathrm{l}$ clavulanic acid,

$x$ control assay; standard conditions. the monobactam aztreonam) cannot be determined enzymatically either because they lack affinity for the enzymes, or they show non-competitive inhibition of enzyme activity.

The assay remained unaffected by $100 \mathrm{mg} / \mathrm{l}$ gentamicin, tetracycline, erythromycin, rifampicin, fusidic acid, fosfomycin, and the quinolone compound ofloxacin.

\section{Combination of $\beta$-lactam antibiotics}

The enzymatic assay cannot be used for combinations of $2 \beta$-lactam compounds, when both are stable to hydrolysis by the enzyme employed, and both exhibit high affinity for the enzyme. Ampicillin and mezlocillin are used widely in combination with oxacillin. In this case oxacillin levels can be easily determined after pre-incubation with the enzyme from Proteus vulgaris, as ampicillin and mezlocillin are rapidly inactivated (fig. 3). For this purpose the assay has to be modified as follows:

$0.40 \mathrm{ml}$ buffer containing the enzyme and

$0.02 \mathrm{ml}$ sample;

mix and incubate $\left(25^{\circ} \mathrm{C}\right.$ or $\left.37^{\circ} \mathrm{C}\right)$ for approximately 30 minutes; add $0.02 \mathrm{ml}$ substrate solution $(9.5 \times$ $10^{-4} \mathrm{~mol} / 1$ PADAC $\left.{ }^{(}\right)$and measure decrease in absorbance at $575 \mathrm{~nm}$ for 1 or 2 minutes.
As clavulanic acid exhibits time-dependent progressive inhibition of enzyme activity after some minutes, this modified assay cannot be used for the determination of clavulanic acid in the presence of ampicillin or amoxycillin (fig. 3 ).

\section{Within-run and day to day precision}

Within-run precision revealed C. V.s between 3.7 and $4.4 \%$ for all $\beta$-lactam antibiotics. Day to day precision revealed a C. V. of $6.7 \%$ for cefotaxime.

Comparison of the enzymatic with the microbiological procedure

A comparison of both procedures was performed for piperacillin, cefotaxime, and imipenem. There were good correlations between both procedures for all three compounds: for imipenem $r$ was 0.988 ( $y=$ $0.968 x-0.07)$ for the 12 serum samples, and 0.845 $(y=1.01 x+0.91)$ for the 11 bile samples; overall correlation resulted in $\mathrm{r}=0.988(\mathrm{y}=0.951 \mathrm{x}+0.62)$ (fig. 4a). For cefotaxime (16 serum samples) $\mathrm{r}$ was $0.968(\mathrm{y}=0.78 \mathrm{x}+1.19$ ) (fig. $4 \mathrm{~b}$ ) and for piperacillin $0.989(\mathrm{y}=1.03 \mathrm{x}-5.7)$ (data for piperacillin not shown). 


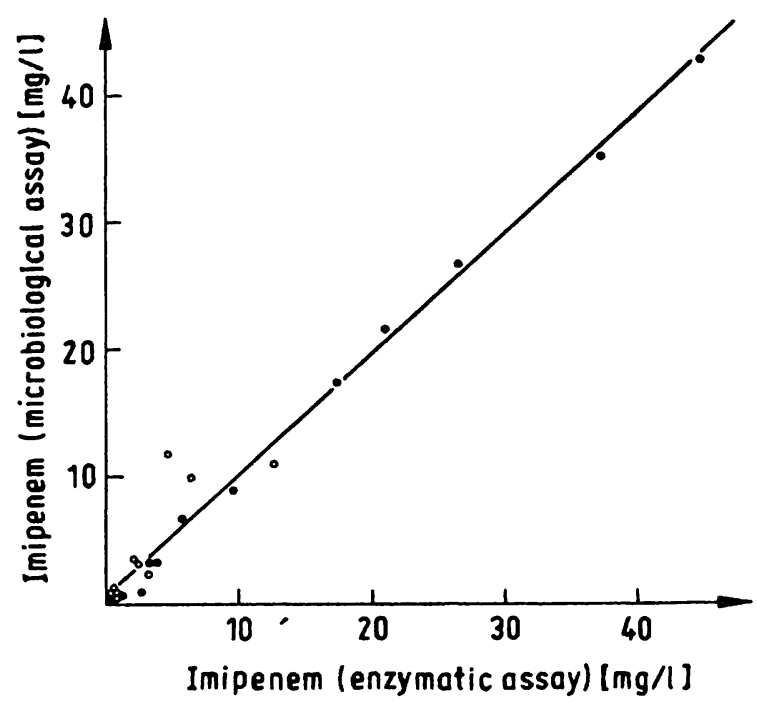

Fig. 4a. Comparison of the enzymatic with the microbiological procedure for imipenem (12 serum and 11 bile samples).

O serum, $O$ bile;

$y=0.949 x+0.688, r=0.988, p<0.001$.

\section{Discussion}

In view of the reported occurrence of side effects from $\beta$-lactam antibiotics, a rapid procedure for monitoring these compounds is needed. Above all, such an assay should be easy to perform and provide results within a few hours.

Our findings clearly demonstrate that the enzymatic assay is as sensitive as the standard procedures and requires only a small sample volume, which may be of advantage with respect to pediatric patients. The wide spread use of $\beta$-lactam antibiotics in combination with aminoglycosides or macrolides is often associated with analytical problems; however, the enzymatic assay does not interfere with antibiotics other than $\beta$-lactam compounds. The sensitivity of the enzymatic assay deserves special attention for the pharmacokinetic evaluation of new compounds exhibiting high affinity for one of the various enzymes. Some compounds, such as cefotaxime, are subject to metabolism, but the de-acetyl derivative does not affect the assay because of its lowered affinity to the enzyme (3). This aspect deserves attention, as the de-acetyl derivative exhibits only weak antibacterial activity (3).

It can be seen that the assay is of limited value for combinations of $2 \beta$-lactam antibiotics. In combinations of ampicillin or mezlocillin with oxacillin however, oxacillin concentrations can be determined with the Proteus vulgaris enzyme. This procedure is

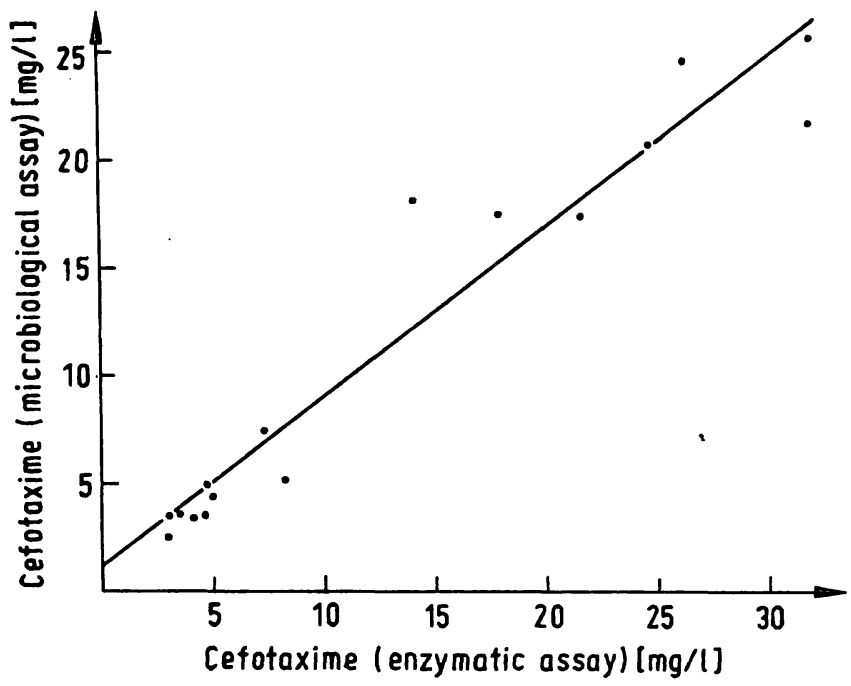

Fig. 4b. Comparison of the enzymatic with the microbiological procedure for cefotaxime (16 serum samples); $\mathrm{y}=0.796 \mathrm{x}+1.18, \mathrm{r}=0.968, \mathrm{p}<0.001$.

somewhat easier to handle than the microbiological procedure, which requires destruction of ampicillin prior to the assay.

The interaction of clavulanic acid with the Proteus vulgaris enzyme deserves further characterization. A mechanism related to that reported for the Escherichia coli TEM-1 enzyme may be assumed (9), i. e. the first step of the interaction of clavulanic acid with the enzyme can be considered to be competitive, followed by a progressive irreversible inactivation of the enzyme.

The determination of imipenem by conventional procedures provides severe problems, because of the instability of the drug during storage and change of temperature. Therefore, the enzymatic assay can be employed with advantage, thereby overcoming the slow nonspecific breakdown of this agent. This aspect deserves attention in the analysis of bile samples, because the imipenem is less stable at acidic or alkaline $\mathrm{pH}(8)$, which explains the slight discrepancies between the enzymatic and the microbiological procedures.

At the moment interest is focused on the assay of imipenem, methoxy-imino cephalosporins, and lamoxactam. Unfortunately, lamoxactam lacks either binding or competitive inhibition of the above $\beta$ lactamases. With the characterization of further enzymes, assay procedures will become available for those compounds that cannot be assayed at present. 


\section{References}

1. Dick, W. \& Cullmann, W. (1984) Fresenius Z. Anal. Chem. $317,717-718$.

2. Barza, M. \& Lauermann, M. (1978) Clin. Pharmakokinetics 3, 202-215.

3. Seibert, G. \& Biebach, A. (1981) J. Clin. Chem. Clin. Biochem. 19, 279-282.

4. Schindler, P. \& Huber, G. (1980) In: Enzyme Inhibitors (Brodbeck, U., ed.) pp. 169-176. Verlag Chemie, Weinheim.

5. Cullmann, W. (1985) Chemotherapy (Basel), in press.

6. Norrby, S. R., Alestig, K., Björngard, B., Burman, L. A., Ferber, F., Huber, J. L., Jones, K. H., Kahan, F, M., Kahan, J. S., Kropp, H., Meisinger, M. A. P. \& Sundelof, J. G. (1983) Antimicrob. Agents Chemother. 23, 300 - 307.

7. Cullmann, W. \& Dick, W. (1983) Zbl. Bakt. Hyg., I. Abt. Orig. A 254, 413-422.

8. Norrby, S. R., Björnegard, B., Ferber,' F. \& Jones, K.H. (1983) J. Antimicrob. Chemotherapy (Suppl. D) 12, 109-124.

9. Charnas, R. L., Fisher, J. \& Knowles, J. R. (1978) Biochemistry $17,2185-2189$.

Dr. Wolfgang Cullmann Lehrstuhl für Med. Mikrobiologie und Immunologie der Ruhr-Universität Bochum Postfach 102148 D-4630 Bochum 1 